\title{
Case History of an Eighteen-Year-Old Stutterer
}

by

JOY BLOCH. B.A.Log.(Rand).

An intelligent 18-year-old male stutterer, who has been receiving speech therapy at the University of the Witwatersrand Speech, Voice and Hearing Clinic, for the past two years, was asked to write on his experiences as a stutterer. His response, in the writer's opinion, contains much valuable information, and appears to indicate many insights and a change of attitude. It is presented here (with his permission), in the hope that it will be of interest to therapists in this field. A brief outline of his case history, together with an outline of the type of therapy given, will be included to supplement and place in context his contribution.

In order to preserve the case's anonymity he will be referred to as "Peter".

\section{CASE HISTORY}

Peter lives with his mother and his sister, who is six years older than he is. His father died when he was in his final school year. He started stuttering when he was about $2 \frac{1}{2}$, when he began forming sentences. $\mathrm{He}$ was fairly slow in starting to speak. Other developmental milestones were normal. There is no history of stuttering in the family.

He obtained a first class matriculation pass, and is at present repeating his first year as a medical student. He intends becoming a psychiatrist.

$\mathrm{He}$ has had a variety of therapies at various times, including speech therapy, hypnotherapy and psychotherapy. He was first seen at the University Speech Clinic when he was six, and he received a short period of therapy. After this he received therapy in the school situation. He was interviewed again at the Clinic when he was 14 , but did not receive therapy. He returned to the Clinic in May 1961, and for a year received both group and individual therapy. Apparently he did not relate well in the group, and it was decided that he receive only individual therapy this year.

In conjunction with speech therapy he is receiving psychiatric treatment.

It is reported that he had severe guilt feelings on the death of his father, and tends to be dominated by his sister and his mother. He apparently sets high standards for himself. He has threatened to commit suicide on several occasions.

An account of his reactions to therapy and his general behaviour pattern will be given later in this paper.

\section{DESCRIPTION OF SYMPTOM}

Peter is a severe secondary stutterer. When he was seen at the Clinic in May 1961, his stutter consisted of tense repetitions and non-vocalized blocks accompanied by secondary symptoms of lip tremor, pursing of the lips, constant head nodding and jerking, and clicking of the tongue. He kept eye-contact for a part of each block. According to the interviewing clinician: "He frequently gave up the speech attempt. This was his most characteristic method of handling severe blocks. At these times, when tension was extreme during the spasm, he would almost break down and cry, remain silent, or would say "leave it" or "it doesn't matter". When pressed to continue he would become almost catastrophic. His obvious anxiety at his stuttering manifested itself in such physical symptoms as blushing, sweating and constant movements."

When first seen by the present clinician his stutter consisted of tense repetitions, drawing out of the end part of a word to carry him on to the next, and some non-vocalised blocks accompanied by somewhat bizarre secondary symptoms of head nodding, eye-blinking, tremor of lips and jaw, and facial grimacing. He frequently blushed during a block, and occasionally broke out into a sweat. He used starters such as "well", went back on words that he could not say, and on rare occasions, when he had a particularly severe block, tended to give up the speech attempt completely. He sounded as 
though he was "running short of breath", his general speech pattern having. a very breathless quality. He maintained a certain amount of eye-contact during a block. He reported tension in the stomach area when stuttering.

\section{THERAPY}

Peter received therapy on similar lines from two different clinicians. His previous clinician reported many of the difficulties encountered by the writer.

Peter was resistant to therapy from the start. He appeared to be arrogant and was resentful of the clinic, since here he had to face his stuttering and himself as a stutterer. Moreover, he was treated as a stutterer, and this seemed to increase his resentment. He maintained that he would never accept himself as a stutterer, as this was tantamount to an admission of failure on his part, as what he wanted was complete fluency. He blamed all his failures and inadequacies on his stuttering, including academic, social and emotional failures.

Initially the writer had difficulty in establishing an adequate working relationship with Peter. He made several attempts to discontinue therapy, usually giving very immature reasons. He would become excited and emotional when his immature rationalisations were pointed out to him, and this served only to increase his aggression and resentment. Gradually the writer came to accept him as he was, and indicate her acceptance of him by not responding to him as other people usually did, i.e. with aggression and pity. This seemed to be a turning point in therapy, as from then on Peter became more co-operative, and less prone to bouts of extreme excitability and aggression.

Peter was subject to periods of extreme depression. When depressed, he would frequently respond by becoming silent and looking down, or alternatively would become excited and start to shout. When shouting, his speech was often fluent. Peter talked freely and frankly about his feelings, and would place the ultimate blame for his depression:on his stutter. An attempt was made to discuss with him his assets and liabilities. To him, all his assets (he was quite frank about these and maintained he was superior to others in every way except in speech) were outweighed by the liability of his stuttering.

This attitude hampered attempts to modify his stuttering, in that in the therapy situation, knowing that he was regarded as a stutterer, he was quite willing to stutter "openly" without avoidances. However, he was extremely reluctant to do this in any situation outside the clinic, especially with people who were not aware of his stuttering. In the clinic situation Peter was able to stutter easily, with relatively little struggle, and was able to modify his symptoms in the various ways suggested, always being aware of what he was doing, and being able to discriminate the form the modifications took. $\mathrm{He}$ "did not like" the easy, "open" stuttering as the "stutterings lasted longer" than those of his usual pattern. The lengths of the easy and tense blocks were timed with a stop watch, and although the average difference in duration was negligible, Peter maintained that the easy blocks "felt longer".

Peter was often loath to use the taperecorder when working on his stutter, as it made his "greatest liability" even more real to him. Although he used the tape recorder frequently, he always appeared upset when hearing the play-back, and when he was depressed would refuse to use the recorder at all.

Peter admitted to having a fear of talking on the telephone. This was discussed, and he eventually carried out several telephone assignments in the clinic situation only. He would not 'phone outsiders. He reported that he used the telephone at home only when necessary.

As therapy progressed, a change became evident in his symptoms. He rarely gave up speech attempts completely. He eliminated the use of starters to a certain extent, and would carry through with his blocks until he was able to release the word. He was also able to maintain eye-contact for most of the time, except when having a particularly severe block.

I would now like to present his contribution on:

\section{“MY EXPERIENCES AS A STUTTERER."}

"It must be difficult, well nigh impossible for non-stutterers to imagine what it is like to be a stutterer. To be reluctant to enter a shop to buy a box of matches or to pick up 
a telephone, to be loath to speak to members of the opposite sex - nonsense! Speech is as natural as breathing, walking or eating to be done automatically, without thought.

As a stutterer, I will try to explain why a stutterer acts as he does and what he experiences due to his inability to converse freely on a purely physical level. Stutterers are only bound to one another by the bond of their stutter and therefore there is no specific "stuttering-type". The following lines, while they might well be applicable to many stutterers, only refer specifically to myself and must not be taken to be typical of all stutterers. If stutterers all conformed to one mental attitude, treatment of stuttering would be a comparatively easy matter. However - "vive-la-difference!"

As a stutterer I soon developed the "giant in chains" attitude. What would I not achieve if I had normal speech! I do not think that I might be but a mediocrity if I did speak fluently. As I cannot, as it were, prove my mediocrity by normal means of expression, and I am forced to take a back seat due to my stutter, the stutter is then blamed for all my failures. It is a convenient scapegoat.

However, the stutter is not completely guiltless. To a very appreciable extent, it has governed my growth of personality besides affecting me on a physical level.

Due to the stutter, I have learned to converse practically in monosyllables and to say in a very few words almost what $I$ intend to convey. Brevity precludes excess stuttering! A certain sharpness of tongue results and because these few words can usually be said without stuttering, we find our "fettered gaint", the "false fluency" having gone to his head, ironically being labelled a "chatterbox". Also in my case, trying to be noted not for how I speak, but for what I say, I do not exactly exercise tact in my speech. For one who has a speech difficulty, I manage quite well to make my likes and dislikes known in no mean manner. Incidentally I am also quite a successful heckler of university lecturers, no mean achievement for a stutterer in a most competitive field!

Of course, due to my failure in person to person relationships, I have tried to make up for this shortcoming by constantly trying to prove my superiority, or at least my "uninferiority" in other fields of endeavour, e.g. sport. To this end I improved myself in these fields - for example becoming a good dancer - and thus have tried to show that I am "one of the boys" even if I am a stutterer. But to my mind, all of these assets do not outweigh the liability of my stutter. The stutter, in fact, has assumed dimensions out of all proportion to its actual place in my personality make-up. Undoubtedly it has become the most important factor in my life and due to my inability to rid myself of it for I feel that I do not need it any more I spend much time in deep bouts of depression which alternate with forced gaiety.

No stutterer wants to continue stuttering all his life. One outgrows the need for this escape mechanism from the responsibilities of everyday life - for what better escape is there than a speech defect which prevents the stutterer from speaking freely? I find I have outgrown the need to stutter, but I am "stuck with it". My frantic efforts to disguise, hide or loose it, often using misguided methods, only makes the stutter worse and I experience a deep sense of guilt in failing myself and the people interested in my welfare by not speaking fluently.

I, as a stutterer, developed a deep sense of frustration and resentment against my fate and also an infinite propensity for self-pity. In an effort to hide my stutter I exhibited a strange mixture of arrogance and shyness. To most people I present the facade of a terrible "holier than thou" attitude of aloofness, my reasoning being rather to be thought "stuck up" than to reveal myself as a stutterer. I find it hard to believe that people can accept me together with my stutter and at times I feel apologetic for subjecting them to my stutter. Sometimes I feel aggressive, as it were daring them to laugh at me. and I might add, being slightly disappointed when they do not!

But I am also shy, as I am terrified of being found out as a stutterer and exposed to laughter or, as happens more often, pity. For I have found that on the whole people are more sympathetic and understanding, which rather rankles, as I do not like being placed in a position whereby people have cause to exhibit sympathy. I would much rather be the dispenser of sympathy than the recipient.

On many occasions I have preferred to be thought arrogant, a fool, or simply mad, 
rather than reveal the fact that I stuttered or that I stuttered badly, for in normal speech, not resorting to monosyllables, it is practically impossible to hide a stutter completely. Also I have let people think a statement of mine means one thing, when I meant something totally different, rather than have to explain myself and stutter over the explanation.

One recent example of the misunderstanding caused by my stutter happened at University. A girl in my class, whom I rather fancied, was wearing a low necked blouse with a Star of David very much in evidence round her neck. Referring to the medallion, I asked her pleasantly whether she was advertising. To my consternation she misunderstood the remark and rather than have to stutter the explanation - at that time she did not know that I stuttered - I left her with a totally erroneous impression of my harmless little remark.

There are many such examples of times I have awkwardly kept silent whilst with people, being though a boor because of my taciturnity. I have also agreed with complete lies to escape the embarrassment and bother of "stutter-explaining".

Being "imperfect in speech", I have set myself a very high standard of "perfection" which even a superman would find taxing. Every success is deprecated, but failures are magnified out of true proportion, and of course blamed on my stutter. What ingenuity is evidenced in blaming even moderate success on my stutter! If I had not stuttered the success would have been far greater.

This preciosity is perhaps the most lasting and far-reaching effect of my stutter. Perhaps I can learn to live with the physical fact of my stutter, but unless I revise my thinking very radically, psychologically I will never be able to make the most of my opportunities and become adjusted to the restrictions imposed by my handicap."

In the writer's opinion, Peter's paper reflects an intellectual insight and appreciation of his problems. It also seems to indicate a growing awareness of the need to face up to and accept the fact of his stuttering. Once he has achieved this, the path of therapy should be easier.

\section{SUMMARY}

An intelligent 18-year-old male stutterer, who attends the Speech Clinic, University of the Witwatersrand, was asked to write on his experiences as a stutterer. As his paper, in the writer's opinion, contains meny insights and a change of attitude, it was presented in the hope that it would be of interest to therapists in the field. An outline of his case hisory, together with a brief outline of the type of therapy given, were included to place his contribution in context.

\section{OPSOMMING}

'n Intelligente, agtienjarige hakkelaar, wat by die Spraakkliniek van die Universiteit van die Witwatersrand behandeling ontvang, is versoek om sy ondervindings as 'n hakkelaar te beskryf. Aangesien sy beskrywing, volgens die opsteller se mening, ' $n$ insig in sy probleem en 'n verandering van houding toon, word dit aangebied met die hoop dat dit van belang mag wees vir terapeute op die gebied. 'n Oorsig van sy gevalsgeskiedenis, tesame met 'n kort oorsig van die terapie toegepas, is ingesluit om 'n geheelbeeld van sy bydrae te gee.

\section{REFERENCES.}

Van Riper, C. "Speech Correction - Principles and Methods". Prentice-Hall Inc., New Jersey, Revised Edition - 1954

Booklet. "On Stuttering and its Treatment". Report of a Conference held at Nassau, Bahamas in Jan. 1960. Sponsored by the Speech Foundation of America. 